DOI: https://doi.org/10.47405/mjssh.v5i6.434

\begin{tabular}{|c|c|}
\hline 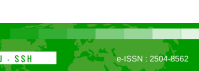 & Malaysian Journal of Social Sciences and Humanities (MJSSH) \\
\hline Malaysian Journal of & Volume 5, Issue 6, June 2020 \\
\hline (MJ - SSH) & e-ISSN : 2504-8562 \\
\hline & $\begin{array}{l}\text { Journal home page: } \\
\text { www.msocialsciences.com }\end{array}$ \\
\hline
\end{tabular}

\title{
Hubungan Antara Kepimpinan Transformasi Guru Besar dengan Komitmen Kerja dalam kalangan Guru Sekolah Rendah di Daerah Kulim Bandar Baharu, Kedah
}

\author{
Saravanan Munian', Shahizan Hasan² \\ ${ }^{1}$ Sekolah Jenis Kebangsaan (Tamil), SJK (T) Ganesar, Kedah \\ 2Pusat Pengajian Ilmu Pendidikan, Universiti Sains Malaysia (USM) \\ Correspondence: Saravanan Munian (dr.saravananshiva@gmail.com)
}

\begin{abstract}
Abstrak
Komitmen kerja guru memainkan peranan penting dalam meningkatkan prestasi sesebuah organisasi sekolah. Peranan gaya kepemimpinan transformasi dapat membantu dalam meningkatkan komitmen kerja guru bagi mencapai matlamat sekolah. Tujuan penyelidikan ini adalah untuk mengkaji hubungan antara gaya kepemimpinan transformasi guru besar dengan komitmen kerja di kalangan guru Sekolah Jenis Kebangsaan Tamil di daerah Kulim Bandar Baharu, Kedah. Sampel kajian ini terdiri daripada 200 orang guru dari 17 buah Sekolah Jenis Kebangsaan Tamil di daerah Kulim Bandar Baharu yang dipilih secara rawak. Soal selidik kajian tinjauan ini mengandungi 62 item dan mempunyai kebolehpercayaan yang tinggi dengan nilai Cronbach Alpha sebanyak 0.96 (Bahagian B) dan 0.95 (Bahagian C). Data kajian ini dianalisis dengan menggunakan statistik deskriptif dan Analisis Korelasi Pearson. Dapatan deskriptif menunjukkan bahawa tahap komitmen kerja dalam kalangan guru Sekolah Jenis Kebangsaan Tamil di daerah Kulim Bandar Baharu adalah tinggi. Seterusnya, analisis Korelasi Pearson menunjukkan bahawa terdapat hubungan signifikan yang positif dan sederhana antara gaya kepemimpinan transformasi guru besar dengan komitmen kerja dalam kalangan guru Sekolah Jenis Kebangsaan Tamil di daerah Kulim Bandar Baharu. Di samping itu, analisis Korelasi Pearson turut menunjukkan bahawa terdapat hubungan signifikan yang positif dan lemah antara dimensi-dimensi gaya kepemimpinan transformasi guru besar seperti karismatik, motivasi inspirasi, stimulasi intelektual dan pertimbangan secara individu dengan komitmen kerja dalam kalangan guru Sekolah Jenis Kebangsaan Tamil di daerah Kulim Bandar Baharu. Secara keseluruhannya, kajian ini mendapati bahawa gaya kepemimpinan transformasi guru besar mempunyai hubungan yang signifikan dengan komitmen kerja guru.
\end{abstract}

Kata kunci: gaya kepimpinan, transformasi guru besar, komitmen kerja

\section{Relationship Between Headmaster's Transformation Leadership and Work Commitment Among Primary School Teachers in Kulim Bandar Baru, Kedah}

\begin{abstract}
The commitment of teachers plays a key role in improving the performance of a school. The role of transformation leadership styles can help to enhance the work commitment of teachers to achieving the goals of the school the purpose of this research was to study the relationship between the leadership style of the headmaster transformation and the work commitment among the Tamil National Kindergarten teachers in the district of Kulim Bandar Baru, Kedah. The sample of this study consisted of 200 teachers from 17 Tamil National Type Schools in Kulim Bandar Baru district which were
\end{abstract}


randomly selected. The survey questionnaire contained 62 items and had high reliability with Cronbach Alpha values of 0.96 (Section B) and 0.95 (Section C). The data of this study were analyzed using descriptive statistics and Pearson Correlation Analysis. The descriptive findings indicate that the level of work commitment among Tamil National Kindergarten teachers in Kulim Bandar Baru is high. Furthermore, Pearson Correlation analysis shows that there is a positive significance and weak relationship between the transformational leadership styles of the headmaster and the work commitment among the Tamil National School teachers in the Kulim Bandar Baru district. In addition, Pearson Correlation analysis also shows that there is a positive significance and weak relationship between the dimensions of leadership style in the transformational (headmasters) such as charismatic, inspirational, intellectual stimulation and individual consideration with work commitment among Tamil National Kindergarten teachers in the region Kulim New Town. Overall, this study has found that the leadership style of transformational headmasters has a significant relationship with teacher work commitment.

Keywords: leadership style, teacher transformation, work commitment

\section{Pengenalan}

Pada abad ke 21 ini, kemajuan serta perkembangan bidang Sains dan Teknologi telah menjadikan kesemua negara berubah menjadi dunia tanpa sempadan. Berhubung dengan itu, bagi mencapai matlamat wawasan 2020, negara Malaysia perlu melahirkan tenaga kerja yang mahir sepenuhnya. Maka, bidang pendidikan dijadikan fokus utama bagi melahirkan modal insan yang seimbang dari segi jasmani, emosi, rohani dan intelek.

Justeru, Kementerian Pelajaran Malaysia telah merangka pelbagai jenis langkah bagi mentransformasikan bidang pendidikan negara. Pada tahun 2011, Pelan Pembangunan Pendidikan Malaysia (2013-2025) telah dilancarkan di peringkat sekolah secara rasminya. Pelan Pembangunan Pendidikan Malaysia ini merangkumi 11 anjakan yang utama. Salah satunya adalah 'Memastikan Kepimpinan Berprestasi Tinggi Ditempatkan Setiap Sekolah'. Namun, bagi merealisasikan aspirasi negara, guru besar dan guru-guru seharusnya bekerjasama demi menjayakan visi dan misi sekolah. Dalam konteks kajian luar negara, apabila perubahan berlaku dalam bidang pendidikan, sekolah memerlukan pemimpin yang mempunyai visi bagi merangsang minda guru untuk bertindak secara kolektif. Kajian-kajian yang lain pula turut memberikan dapatan yang sama iaitu pemimpin sekolah yang mempunyai hubungan yang baik dengan guru-guru dapat memperolehi kerjasama yang baik daripada mereka bagi mencapai matlamat organisasi (Hoy \& Miskel 2005; Lunenberg \& Ornstein 2000). Menurut Mosadeghard (2003), terdapat beberapa jenis kepimpinan iaitu autokratik, birokratik, laissez-faire, karismatik, demokratik, transaksional, transformasional serta sebagainya. Menurut Bass (1990), pemimpin transformasi ialah pemimpin yang dapat mempengaruhi dan menyumbang kepada pembangunan individu di bawahnya untuk mencapai prestasi dan komitmen yang tinggi. Sehubungan dengan itu, dalam konteks Malaysia Ishak Sin (2001) mendapati kepimpinan transformasi di negara Malaysia memainkan peranan yang tinggi terhadap komitmen dan kepuasan kerja guru berbanding gaya kepemimpinan yang lain. Selain itu, komitmen guru turut memainkan peranan penting dalam meningkatkan prestasi sesebuah organisasi sekolah. Menurut Meyer \& Allen (1997), komitmen dikaitkan dengan perasaan emosi, idea, falsafah dan nilai yang dipegang oleh seseorang ahli organisasi semasa menjalankan tanggungjawabnya. Lazimnya, komitmen guru dibahagikan kepada tiga dimensi iaitu komitmen terhadap sekolah, komitmen terhadap pengajaran serta komitmen terhadap murid-murid (Insim Park 2005).

Sejak kebalakangan, organisasi sekolah sering menghadapi berbagai-bagai jenis masalah pengurusan pendidikan seperti pincanglaku pengetua, ketidakhadiran guru, kelewatan guru masuk kerja, guru bertekanan tinggi, ketidakseriusan guru dalam pengajaran, tahap komitmen kerja guru yang rendah, guru bermasalah disiplin, prestasi sekolah yang rendah dan sebagainya (Fauziah, Rahmah, Rohani, Rasimah \& Zabani, 2008; Tang \& Abdul Ghani, 2006). Masalah-masalah ini adalah berkaitan dengan komitmen kerja yang diberikan oleh seseorang guru di setiap sekolah. Pernyataan masalah kajian ini 
membincangkan tiga masalah utama yang digariskan sebagai persoalan kajian dalam penyelidikan ini. Pertama, tahap komitmen kerja guru-guru di sekolah sentiasa berubah perubahan gaya kepemimpinan guru besar serta perubahan persekitaraan sekolah. Jasa mereka kurang dipupuk dalam mengasahkan keupayaan diri supaya bertindak secara inovatif dan kreatif. Kedua, peranan kepemimpinan transformasi yang lemah tidak dapat mengekalkan komitmen kerja guru sekolah bagi mencapai matlamat sekolah. Ketiga, kebanyakkan guru sering mengadu bahawa para guru besar mereka tidak bersikap karismatik lalu gagal menjadi teladan atau contoh kepada para guru di sekolah dan juga kurang mengambil berat terhadap masalah dan keperluan kakitangannya. Dalam situasi ini, guru besar kurang memotivasikan ahli organisasinya supaya menjadi sebuah pasukan yang bersemangat tinggi. Kegagalan bertindak sedemikian akan melahirkan persekitaraan sekolah yang kurang berkomitmen terhadap organisasi sekolah. Berdasarkan kepada penyataan di atas, masalah kajian ini akan menggabungkan dua pembolehubah iaitu kepemimpinan transformasi guru besar dan komitmen kerja guru dalam konteks pendidikan di Malaysia. Dalam pada itu, kajian ini dijalankan untuk menjadi alternatif penyelesaian kepada masalah-masalah yang wujud di sekolah sepertimana yang dinyatakan di atas supaya organisasi sekolah dapat berfungsi secara sistematik dan berkesan.

Oleh sedemikian, tujuan utama kajian ini adalah untuk mengkaji hubungan antara gaya kepemimpinan transformasi guru besar dengan komitmen kerja dalam kalangan guru-guru Sekolah Jenis Kebangsaan Tamil daerah Kulim Bandar Baharu di negeri Kedah. Kajian ini dapat memberikan gambaran dan maklumat yang jelas mengenai corak kepemimpinan transformasi guru besar yang dapat membentuk para guru yang berkomitmen tinggi di Sekolah Jenis Kebangsaan Tamil di daerah Kulim Bandar Baharu, Kedah. Dapatan kajian ini boleh dijadikan bahan rujukan kepada kajian-kajian yang akan mengkaji aspek kepemimpinan transformasi di Sekolah Jenis Kebangsaan Tamil dan Sekolah Jenis Kebangsaan Cina, sekolah menengah ataupun di institut pengajian tinggi. Kajian ini melibatkan 17 buah Sekolah Jenis Kebangsaan Tamil di daerah Kulim dan Bandar Baharu yang berada di bawah penyeliaan Pejabat Pelajaran Daerah Kulim Bandar Baharu (PPDKBB) dan responden kajian ini ialah guru-guru dari Sekolah Jenis Kebangsaan Tamil di daerah Kulim Bandar Baharu, Kedah.

\section{Sorotan Literatur}

Kajian ini dijalankan bagi mengetahui hubungan antara kepemimpinan transformasi guru besar dengan komitmen kerja guru Sekolah Jenis Kebangsaan Tamil di daerah Kulim Bandar Baharu. Oleh itu, definisi dan konsep kepemimpinan akan di bincangkan secara lebih mendalam.

\section{Gaya Kepemimpinan Transformasi Guru Besar}

Dalam sesebuah organisasi, pemimpin memainkan peranan yang sangat penting (Lunenberg \& Ornstein, 2000; Sergiovanni, 2001). Menurut Yukl (2002) pula, kepemimpinan sebagai satu proses mempengaruhi yang melibatkan penetapan matlamat organisasi, tindakan memotivasikan pekerja untuk mencapai matlamat serta mempengaruhi pengekalan budaya sesebuah kumpulan. Dalam pada itu, kepemimpinan juga didefinisikan sebagai satu proses yang berkaitan dengan mendapatkan individu untuk bekerjasama supaya dapat menjayakan sesuatu yang mungkin tidak berlaku tanpa pengaruhnya (Rosenbach \& Taylor, 2001). Selain itu, mengikut konteks pengurusan sekolah kepemimpinan sering dihubungkaitkan dengan pentadbiran yang dijalankan oleh pengetua atau guru besar dan guru-guru penolong kanan. Mengikut pandangan Sergiovanni (2001), terdapat lima peranan guru besar yang mencirikan sifat kepemimpinannya iaitu; a) pemimpin pendidikan, b) pemimpin perhubungan manusia, c) pemimpin teknikal atau juga didefinisikan sebagai jurutera pengurusan, d) pemimpin budaya yang memainkan tugas dalam menyata, menjelas dan meneguhkan nilai-nilai, menyatakan misi dan visi sekolah dan juga memasyarakatkan ahli baru mengikut corak budaya sekolah, e) pemimpin simbolik yang berperanan dalam menerapkan nilai-nilai dan objektif sesuatu perkara yang perlu dicapai, mempunyai wawasan dan menyampaikannya kepada para guru. Selain itu, sebuah badan yang dikenali 'Interstate School Leaders Licensure Consortium' di negara Amerika telah membangunkan standard piawaian bagi seorang pemimpin sekolah pada tahun 1996 dan dikemaskinikan pada tahun 2008. Piawaian ini adalah bertujuan untuk menggariskan tahap penyediaan, pelesenan, induksi serta pembangunan profesionalisme bagi pemimpin sekolah. Antara enam piawaian yang ditetapkan adalah; 
a) menetapkan visi yang dikongsi oleh semua bagi tujuan pembelajaran, b) membangunkan budaya sekolah dan program pembelajaran yang kondusif supaya membantu proses pembelajaran pelajar dan pertumbuhan sifat profesional dalam kalangan kakitangan, c) memastikan keberkesanan pengurusan organisasi, operasi, dan sumber-sumber bagi mewujudkan persekitaran pembelajaran yang selamat ,cekap dan berkesan, d) bekerjasama dengan ahli komunitinya, bertindakbalas terhadap kepelbagaian kepentingan dan keperluan ahli organisasi serta menguruskan sumber-sumber masyarakatnya, e) berkhidmat dengan sifat integriti, adil dan beretika f) memahami, bertindakbalas serta mempengaruhi konteks politik, sosial, undang-undang serta kebudayaan dalam organisasi (Interstate School Leaders Licensure Consortium, 2005).

Ringkasnya, selepas meneliti beberapa pandangan definisi dapat menyimpulkan bahawa kepemimpinan adalah kebolehan, kecekapan, dan kekuasaan yang dimiliki oleh pemimpin untuk menggerakkan ahli organisasinya demi mencapai objektif atau tujuan tertentu. Selain itu, sifat kepemimpinan yang berkesan adalah kebolehan, kewibawaan serta kebijaksanaan pemimpin dalam menguruskan kakitangan bawahannya.

\section{Komitmen Kerja Guru}

Komitmen kerja guru merupakan tingkah laku seseorang individu yang memiliki kepercayaan tinggi terhadap nilai dan matlamat organisasi, semangat sukarela bagi berusaha meningkatkan organisasi serta keinginan yang kukuh untuk terus menetap dan kekal dalam organisasi (Insim-Park, 2005). Menurut Affizal dan Rafidah (2009), komitmen adalah sikap yang menggambarkan kesetiaan pekerja ke atas organisasi dan proses yang berterusan di mana pekerja-pekerja menunjukkan keprihatinan terhadap kejayaan dan kesejahteraan yang berterusan dengan organisasi. Dapatan ini disokong oleh S.G.A Smeenk et al. (2006) bahawa komitmen terhadap organisasi sebagai satu keadaan psikologi yang menjelaskan hubungan di antara seseorang individu dengan organisasinya. Menurut Lapierre (2005), komitmen kerja guru adalah sejenis sikap penting yang mampu menggerakkan pekerja. Komitmen kerja guru berkait rapat dengan tingkah laku, kehadiran harian, kehadiran secara sukarela dan juga pencapaian prestasi kerja. Kebanyakan penyelidikan mengenai konsep komitmen merujuk kepada pendapatan Mowday, Peter dan Steers (1979). Mereka menyatakan bahawa komitmen adalah berhubungkait dengan perasaan, emosi, idea, falsafah dan nilai yang dipegang oleh subordinat semasa melaksanakan tanggungjawabnya kepada organisasi. Proses ini melibatkan nilai, manfaat yang diperolehi serta perasaan individu berkenaan. Menurut Mowday, Peter dan Steers (1979), semakin tinggi perasaan positif terhadap pencapaian dan prestasi yang diingini semakin kuat perasaan komitmen seseorang itu. Komitmen dalam konteks sekolah pula ditakrifkan sebagai satu bentuk ikatan antara guru dengan sekolah yang mempunyai dimensi-dimensinya bagi menjelaskan perhubungan tersebut (Danneta, 2002). Ringkasnya, komitmen dalam organisasi adalah suatu kuasa yang mempengaruhi pekerja untuk bekerja keras dalam organisasinya, yang dipengaruhi oleh psikologi dan motivasi pekerja. Apabila subordinat atau para guru di sekolah meningkatkan tahap komitmen mereka maka penglibatan mereka dalam bidang pekerjaan turut akan meningkat. Ini akan menyebabkan para guru yang dikenali sebagai subordinat dalam organisasi akan menyumbang ke arah kecemerlangan organisasi yang disandarnya.

Banyak kajian telah dilakukan oleh penyelidik-penyelidik dari seluruh dunia bagi mengukur hubungan antara pendekatan kepemimpinan dengan komitmen subordinatnya. Menurut kajian yang dilakukan oleh Yaakob Daud (2007), beliau mendapati gaya kepemimpinan, komitmen organisasi dan pencapaian akademik murid mempunyai hubungan yang signifikan. Dapatan kajiannya menunjukkan bahawa gaya kepemimpinan laissez-faire mempunyai hubungan yang lemah berbanding gaya kepemimpinan transformasi dan transaksi. Dalam pada itu, satu lagi kajian yang mengkaji hubungan antara kepemimpinan dan komitmen terhadap organisasi telah dijalankan di 72 buah institusi kesihatan di negara Uruguay oleh Lagomarsino dan Cardona (2003). Dapatan kajian ini pula menunjukkan bahawa kepemimpinan yang mengutamakan keperluan dan kebajikan kakitangannya akan dapat memperolehi komitmen yang tinggi. Pendekatan kepemimpinan mempunyai pengaruh yang kuat dalam usaha mempertingkatkan komitmen subordinat. Dapatan kajian Lagomarsino dan Cardona (2003) ini lebih menyerupai dapatan kajian yang dilakukan oleh $\mathrm{Wu}$ (2003). Beliau menyatakan bahawa kepemimpinan 
transformasi seperti karismatik dan stimulasi intelektual mempunyai hubungan positif dan kuat terhadap komitmen pekerja.

Ringkasnya, komitmen dalam organisasi adalah suatu kuasa yang mempengaruhi pekerja untuk bekerja keras dalam organisasinya. Komitmen ini dipengaruhi oleh psikologi dan motivasi pekerja. Apabila subordinat atau para guru di sekolah meningkatkan tahap komitmen mereka maka penglibatan mereka dalam bidang pekerjaan turut akan meningkat. Ini akan menyebabkan para guru yang dikenali sebagai subordinat dalam organisasi akan menyumbang ke arah kecemerlangan organisasi yang disandarnya.

\section{Kerangka Teoritikal Kajian}

Kerangka teoritikal kajian yang dipaparkan dalam rajah 1 menunjukkan dua teori asas digunakan dalam kajian ini. Pertama, Teori Kepemimpinan Transformasi Bass dan Avolio (2000) digunakan bagi mengkaji pembolehubah bebas kajian ini iaitu gaya kepemimpinan transformasi guru besar. Terdapat empat dimensi yang dibincangkan dalam Teori Kepemimpinan Transformasi Bass dan Avolio (2000) iaitu karismatik, stimulasi intelektual, pertimbangan secara individu dan motivasi inspirasi. Kedua, Teori Komitmen Organisasi Allen dan Meyer (1990) digunakan bagi mengkaji pembolehubah bersandar kajian ini iaitu komitmen kerja guru. Kerangka teoritikal dalam rajah 1 menunjukkan dengan jelas teori asas yang digunakan dalam kajian ini untuk mengkaji hubungan antara gaya kepemimpinan transformasi guru besar dengan komitmen kerja guru.

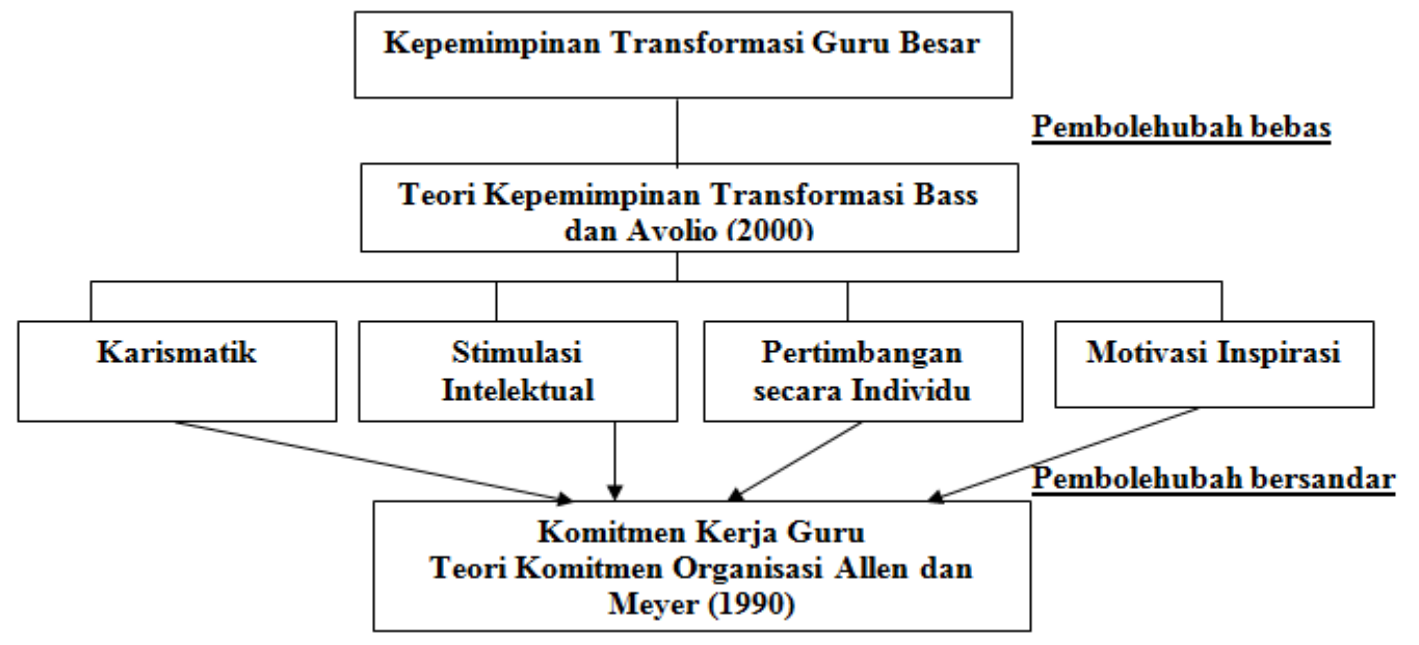

Rajah 1: Kerangka Teoritikal Kajian

Secara keseluruhannya, isu-isu dan sorotan kajian yang merupakan asas kajian ini bagi menjawab persoalan-persoalan kajian. Sorotan kajian memfokuskan kepada pengkajian yang mendalam terhadap isu-isu dan teori-teori yang boleh menyokong penyelesaian masalah kajian. Tinjauan literatur menunjukkan bahawa pendekatan gaya kepemimpinan transformasi amat penting dalam meningkatkan komitmen kerja guru di sekolah. Dapatan daripada penyelidikan-penyelidikan yang lepas mengenai kepemimpinan transformasi telah menunjukkan yang gaya kepemimpinan ini memang sesuai dipraktikkan pada era ini kerana sifatnya yang berkomitmen kepada matlamat serta memberikan perhatian khusus kepada subordinatnya.

\section{Metod Kajian}

Metodologi kajian merupakan aspek penting dalam pelaksanaan sesuatu kajian dengan lancar dan sempurna, kerana ini akan menggambarkan bentuk rangka kerja yang dijalankan dan cara sesebuah kajian itu dilaksanakan agar persoalan yang dikemukakan dapat dijawab. Kajian ini dijalankan bagi mengkaji hubungan antara gaya kepemimpinan transformasi dengan komitmen kerja guru. Kajian ini berbentuk deskriptif yang dijalankan secara kuantitatif. Kaedah deskriptif dapat memberikan gambaran 
fenomena-fenomena yang menunjukkan hubungan antara sesuatu pembolehubah, menguji hipotesis, membuat ramalan serta mendapatkan makna implikasi daripada sesuatu masalah yang ingin diselesaikan. Dapatan ini turut disokong oleh pengkaji-pengkaji lain yang menyatakan kajian secara kuantitatif adalah digunakan bagi menjelaskan keadaan semasa, mengkaji hubungan dan melihat fenomena kesan dan akibat (Gay \& Airasian, 2003). Kaedah tinjauan ini merupakan satu kaedah penyelidikan yang dijalankan bagi mengumpul data daripada populasi dalam satu tempoh masa tertentu sahaja. Jadi, kaedah soal selidik digunakan untuk mengkaji hubungan antara gaya kepemimpinan transformasi guru besar dengan komitmen kerja guru di sekolah rendah.

Menurut Nik Azis (2003), kerangka kajian adalah merujuk kepada struktur idea yang abstrak atau logik yang memandu perancangan, pelaksanaan dan laporan sesuatu kajian. Ini merupakan struktur yang mencantumkan bahagian-bahagian dalam sesuatu kajian untuk membentuk sesuatu keseluruhan. Rajah 2 menerangkan tentang kerangka kajian yang menunjukkan hubungan di antara pembolehubah bebas dan pembolehubah bersandar.

Dalam kajian ini, pembolehubah bebas adalah gaya kepemimpinan transformasi yang terdiri daripada empat dimensi iaitu dimensi karismatik, dimensi pertimbangan secara individu, dimensi stimulasi intelektual dan dimensi motivasi inspirasi (Bass \& Avolio, 2000). Pembolehubah bersandar pula terdiri daripada tiga aspek iaitu aspek afektif, aspek berkekalan, dan aspek normatif (Meyer \& Allen, 1990). Kerangka kajian di atas menunjukkan bahawa pembolehubah bebas dalam kajian ini mempunyai hubungan langsung dengan pembolehubah bersandar.

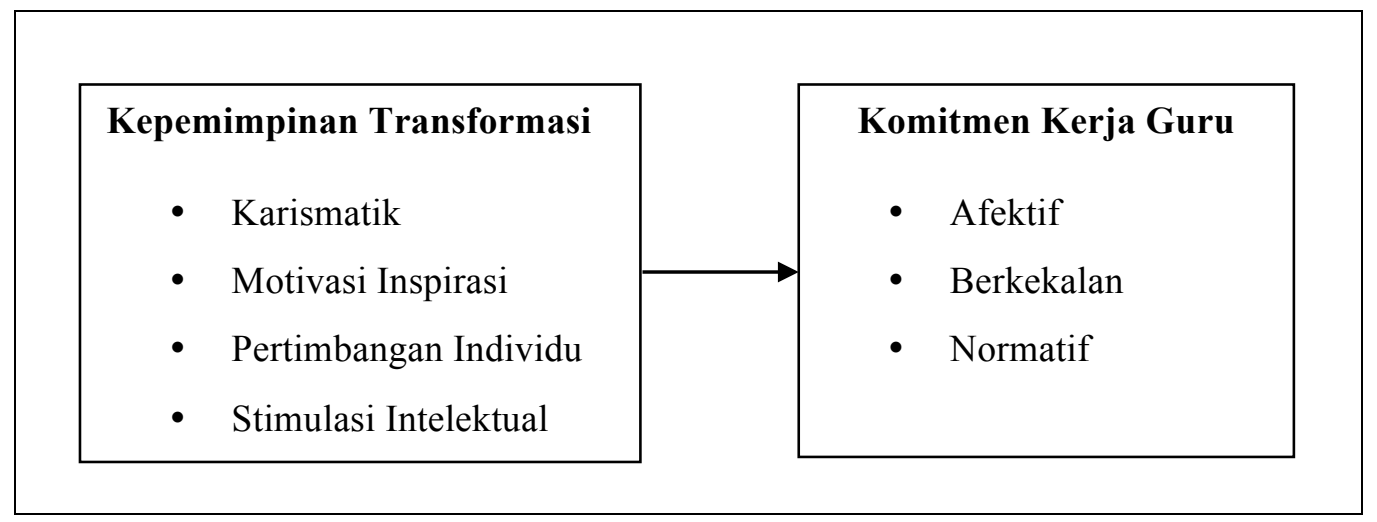

Rajah 2. Kerangka Kajian

\section{Populasi, Sampel Kajian dan Prosedur Analisis Data}

Kajian ini melibatkan 17 buah Sekolah Jenis Kebangsaan Tamil yang terletak di daerah Kulim dan Bandar Baharu di negeri Kedah. Kesemua 17 buah sekolah ini dipilih disebabkan sekolah-sekolah ini terletak di bawah pentadbiran dan penyeliaan Pejabat Pelajaran Daerah Kulim Bandar Baharu (PPDKBB). Dalam kajian ini, populasi kajian adalah terdiri daripada guru-guru yang sedang berkhidmat di daerah Kulim Bandar Baharu iaitu seramai 318 orang dari 17 buah Sekolah Jenis Kebangsaan Tamil. Walaubagaimanapun kajian ini melibatkan sampel guru seramai 200 orang sahaja. Dalam menentukan responden pula, kajian ini menetapkan 2 kriteria iaitu responden perlu berkhidmat sebagai guru Sekolah Jenis Kebangsaan Tamil di daerah Kulim Bandar Baharu dan handaklah berkhidmat dengan guru besar semasa melebihi tempoh satu tahun. Dengan itu, sebanyak 21 peratus daripada sampel juga akan terdiri daripada guru lelaki iaitu sebanyak 42 orang dan 79 peratus guru perempuan iaitu sebanyak 158 orang. Oleh itu, teknik persampelan rawak berstrata mengikut kadar digunakan kerana sampel mewakili kadar nisbah dalam populasi. Dalam kajian ini, teknik soal selidik digunakan sebagai instrumen bagi memperolehi data daripada responden. Data yang diperolehi dianalisis dengan menggunakan Statistical Package for Social Sciences (SPSS) versi 21. Analisis ini melibatkan penggunaan statistik deskriptif seperti taburan kekerapan, sisihan piawai, skor min, dan peratusan bagi menjelaskan ciri-ciri responden kajian ini. Skor min dan sisihan piawai pula digunakan 
bagi mengkaji tahap komitmen kerja guru mengikut jadual tahap analisis min berikut. Selain itu, Korelasi Pearson ' $r$ ' digunakan untuk melihat perhubungan pembolehubah dalam kajian ini iaitu; a) perhubungan antara gaya kepemimpinan transformasi guru besar dengan komitmen kerja guru dan $b$ ) perhubungan antara dimensi-dimensi gaya kepemimpinan transformasi guru besar dengan komitmen kerja guru.

\section{Dapatan Kajian}

Dalam kajian ini, sebanyak 230 set soal selidik telah diedarkan kepada 17 buah Sekolah Jenis Kebangsaan Tamil yang terletak di daerah Kulim Bandar Baharu. Sebanyak 200 set soal selidik iaitu 87 peratus yang dijawab telah dipungut oleh pengkaji.

Kadar pulangan ini boleh dikatakan sangat memuaskan. Analisis data latarbelakang responden yang meliputi jantina, umur, bilangan tahun perkhidmatan dengan guru besar sekarang dan tempoh pengalaman mengajar secara keseluruhan telah dilakukan dalam bahagian ini. Statistik deskriptif digunakan bagi menganalisis kekerapan dan peratusan data latarbelakang responden. Dapatannya dijelaskan dalam jadual 1.

Jadual 1: Taburan Kekerapan dan Peratusan Responden Kajian

\begin{tabular}{lcc}
\hline Demografi & Kekerapan (f) & $\begin{array}{c}\text { Peratusan } \\
\text { (\%) }\end{array}$ \\
\hline Jantina & 42 & 21.0 \\
Lelaki & 158 & 79.0 \\
Perempuan & 200 & 100.0 \\
Jumlah & & \\
\hline Umur & 41 & 20.5 \\
20 hingga 30 tahun & 58 & 29.0 \\
31 hingga 40 tahun & 60 & 30.0 \\
41 hingga 50 tahun & 41 & 20.5 \\
51 ke atas & 200 & 100.0 \\
Jumlah & & \\
\hline Bilangan Tahun Perkhidmatan dengan Guru Besar & & \\
Sekarang & 42 & 21.0 \\
1 hingga 5 tahun & 58 & 29.0 \\
6 hingga 10 tahun & 59 & 29.5 \\
11 hingga 20 tahun & 41 & 20.5 \\
21 tahun ke atas & 200 & 100.0 \\
Jumlah & & \\
\hline Pengalaman Mengajar secara Keseluruhan & 43 & 21.5 \\
1 hingga 5 tahun & 57 & 28.5 \\
6 hingga 10 tahun & 59 & 29.5 \\
11 hingga 20 tahun & 20.5 \\
Jumlah ke atas & 41 & 100.0 \\
\hline
\end{tabular}

Analisis deskriptif dijalankan bagi menjawab kepada persoalan pertama kajian ini. Analisis deskriptif yang melibatkan min dan sisihan piawai telah digunakan bagi mengkaji tahap komitmen kerja dalam kalangan guru-guru Sekolah Jenis Kebangsaan Tamil di daerah Kulim Bandar Baharu. Dapatannya dijelaskan dalam jadual berikut.

Jadual 2: Skor Min dan Sisihan Piawai Komitmen Kerja Guru

\begin{tabular}{lll}
\hline Aspek Komitmen & Min & Sisihan Piawai \\
\hline
\end{tabular}


DOI: https://doi.org/10.47405/mjssh.v5i6.434

\begin{tabular}{lll}
\hline Komitmen Afektif & 4.59 & 0.29 \\
Komitmen Berkekalan & 4.63 & 0.24 \\
Komitmen Normatif & 4.52 & 0.25 \\
\hline Komitmen Keseluruhan & 4.58 & 0.19 \\
\hline
\end{tabular}

Secara keseluruhannya skor min yang diperolehi bagi komitmen kerja dalam kalangan guru di Sekolah Jenis Kebangsaan Tamil di daerah Kulim Bandar Baharu ialah $(\min =4.58$, sisihan piawai=0.19). Dapatan ini menunjukkan bahawa tahap komitmen kerja dalam kalangan guru Sekolah Jenis Kebangsaan Tamil di daerah Kulim Bandar Baharu adalah tinggi. Menurut dapatan ini, aspek komitmen berkekalan adalah menjadi komitmen yang paling dominan iaitu ( $\min =4.63$, sisihan piawai $=0.24)$ manakala aspek komitmen normatif menunjukkan nilai komitmen yang paling rendah iaitu (min= 4.52, sisihan piawai $=0.25$ ). Aspek komitmen afektif pula menunjukkan nilai min sebanyak 4.59 bersamaan dengan sisihan piawai 0.29 . Hasil dapatan analisis ini menunjukkan guru yang terlibat dalam kajian ini mempunyai nilai min purata bagi komitmen kerja sebanyak 4.58. Kesimpulannya, nilai min purata menunjukkan bahawa tahap komitmen kerja dalam kalangan guru Sekolah Jenis Kebangsaan Tamil di daerah Kulim Bandar Baharu adalah tinggi secara keseluruhannya dalam kajian ini.

Sebanyak 9 item telah digunakan untuk mengkaji aspek komitmen afektif dan dapatannya adalah seperti di jadual berikut.

Jadual 3: Kekerapan, Peratusan, Min dan Sisihan Piawai bagi Item- item Aspek Komitmen Afektif

\begin{tabular}{|c|c|c|c|c|c|c|c|c|}
\hline Item & $\begin{array}{c}\text { Sangat } \\
\text { Tidak } \\
\text { Bersetuju }\end{array}$ & $\begin{array}{l}\text { Tidak } \\
\text { Setuju }\end{array}$ & $\begin{array}{l}\text { Tidak } \\
\text { Pasti }\end{array}$ & Setuju & $\begin{array}{l}\text { Sangat } \\
\text { Setuju }\end{array}$ & Min & $\begin{array}{l}\text { Sisihan } \\
\text { Piawai }\end{array}$ & Tahap \\
\hline $\begin{array}{l}\text { Saya berbangga } \\
\text { sekiranya dapat } \\
\text { bertugas di sekolah ini } \\
\text { sepanjang kerjaya }\end{array}$ & $\begin{array}{c}1 \\
(0.5 \%)\end{array}$ & - & - & $\begin{array}{c}39 \\
(19.5 \%)\end{array}$ & $\begin{array}{c}160 \\
(80.0 \%)\end{array}$ & 4.79 & 0.48 & Tinggi \\
\hline $\begin{array}{l}\text { saya. } \\
\text { Saya berasa seronok } \\
\text { apabila dapat } \\
\text { berbincang tentang } \\
\text { sekolah ini dengan } \\
\text { orang luar. }\end{array}$ & - & - & $\begin{array}{l}1 \\
(0.5 \\
\%)\end{array}$ & $\begin{array}{c}128 \\
(64.0 \%)\end{array}$ & $\begin{array}{c}71 \\
(35.5 \%)\end{array}$ & 4.35 & 0.49 & Tinggi \\
\hline $\begin{array}{l}\text { Saya menganggap } \\
\text { masalah sekolah ini } \\
\text { seperti masalah saya } \\
\text { sendiri. }\end{array}$ & $\begin{array}{c}1 \\
(0.5 \%)\end{array}$ & - & - & $\begin{array}{c}55 \\
(27.5 \%)\end{array}$ & $\begin{array}{c}144 \\
(72.0 \%)\end{array}$ & 4.71 & 0.52 & Tinggi \\
\hline $\begin{array}{l}\text { Saya tidak akan berasa } \\
\text { terpaut dengan sekolah } \\
\text { lain. }\end{array}$ & - & - & $\begin{array}{l}1 \\
(0.5 \\
\%)\end{array}$ & $\begin{array}{c}112 \\
(56.0 \%)\end{array}$ & $\begin{array}{c}87 \\
(43.5 \%)\end{array}$ & 4.43 & 0.51 & Tinggi \\
\hline $\begin{array}{l}\text { Saya berasa } \\
\text { sebahagian daripada } \\
\text { keluarga sekolah ini. }\end{array}$ & - & - & $\begin{array}{l}5 \\
(2.5 \\
\%)\end{array}$ & $\begin{array}{c}51 \\
(25.5 \%)\end{array}$ & $\begin{array}{c}144 \\
(72.0 \%)\end{array}$ & 4.70 & 0.51 & Tinggi \\
\hline $\begin{array}{l}\text { Hati saya terpaut } \\
\text { dengan sekolah ini. }\end{array}$ & - & - & $\begin{array}{l}4 \\
(2.0 \\
\%)\end{array}$ & $\begin{array}{c}102 \\
(51.0 \%)\end{array}$ & $\begin{array}{c}94 \\
(47.0 \%)\end{array}$ & 4.45 & 0.54 & Tinggi \\
\hline $\begin{array}{l}\text { Sekolah ini memberi } \\
\text { makna dalam hidup } \\
\text { saya. }\end{array}$ & - & - & $\begin{array}{c}2 \\
(1.0 \\
\%)\end{array}$ & $\begin{array}{c}59 \\
(29.5 \%)\end{array}$ & $\begin{array}{c}139 \\
(69.5 \%)\end{array}$ & 4.69 & 0.49 & Tinggi \\
\hline
\end{tabular}


DOI: https://doi.org/10.47405/mjssh.v5i6.434

\begin{tabular}{|c|c|c|c|c|c|c|c|c|}
\hline $\begin{array}{l}\text { Saya mempunyai } \\
\text { perasaan kekitaan } \\
\text { terhadap sekolah ini. }\end{array}$ & - & - & $\begin{array}{c}4 \\
(2.0 \\
\%)\end{array}$ & $\begin{array}{c}94 \\
(47.0 \%)\end{array}$ & $\begin{array}{c}102 \\
(51.0 \%)\end{array}$ & 4.49 & 0.54 & Tinggi \\
\hline $\begin{array}{l}\text { Saya sukar } \\
\text { meninggalkan sekolah } \\
\text { ini sekarang walaupun } \\
\text { saya ingin berbuat } \\
\text { demikian. }\end{array}$ & - & $\begin{array}{c}1 \\
(0.5 \%)\end{array}$ & - & $\begin{array}{c}57 \\
(28.5 \%)\end{array}$ & $\begin{array}{c}142 \\
(71.0 \%)\end{array}$ & 4.70 & 0.49 & Tinggi \\
\hline
\end{tabular}

Selain itu, sebanyak 8 item telah digunakan untuk mengkaji aspek komitmen berkekalan atau berterusan. Dapatan analisis dalam jadual 3 di atas menunjukkan bahawa item 11 iaitu "saya bimbang apa akan berlaku sekiranyan saya berhenti kerja tanpa ada pekerjaan lain sebagai ganti" memiliki skor min yang paling tinggi iaitu 4.90 bersamaan dengan sisihan piawai 0.31 dengan tahap tinggi. Manakala item 12 iaitu "Meninggalkan sekolah ini sekarang bermakna saya terpaksa menanggung kos yang mahal" pula memaparkan skor min yang paling rendah berbanding dengan item- item yang lain iaitu 4.44 bersamaan dengan sisihan piawai 0.50 . Namun begitu kesemua item dalam aspek komitmen berkekalan menunjukkan tahap yang tinggi kerana nilai min melebihi aras 4.00. Dapatan analisis ditunjukkan seperti dalam jadual 4.

Jadual 4: Kekerapan, Peratusan, Min dan Sisihan Piawai bagi Item- item Aspek Komitmen Berkekalan

\begin{tabular}{|c|c|c|c|c|c|c|c|c|}
\hline Item & $\begin{array}{c}\text { Sangat } \\
\text { Tidak } \\
\text { Bersetuj } \\
\text { u }\end{array}$ & $\begin{array}{l}\text { Tidak } \\
\text { Setuju }\end{array}$ & $\begin{array}{l}\text { Tidak } \\
\text { Pasti }\end{array}$ & Setuju & $\begin{array}{l}\text { Sangat } \\
\text { Setuju }\end{array}$ & Min & $\begin{array}{l}\text { Sisihan } \\
\text { Piawai }\end{array}$ & Tahap \\
\hline $\begin{array}{l}\text { Kehidupan ini akan } \\
\text { terganggu sekiranya } \\
\text { saya mengambil } \\
\text { keputusan untuk } \\
\text { meninggalkan sekolah } \\
\text { ini sekarang. }\end{array}$ & - & - & - & $\begin{array}{c}77 \\
(38.0 \%)\end{array}$ & $\begin{array}{c}123 \\
(61.5 \%)\end{array}$ & 4.62 & 0.49 & Tinggi \\
\hline $\begin{array}{l}\text { Saya bimbang apa akan } \\
\text { berlaku sekiranyan saya } \\
\text { berhenti kerja tanpa ada } \\
\text { pekerjaan lain sebagai } \\
\text { ganti. }\end{array}$ & - & - & - & $\begin{array}{c}21 \\
(10.5 \%)\end{array}$ & $\begin{array}{c}179 \\
(89.5 \%)\end{array}$ & 4.90 & 0.31 & Tinggi \\
\hline $\begin{array}{l}\text { Meninggalkan sekolah } \\
\text { ini sekarang bermakna } \\
\text { saya terpaksa } \\
\text { menanggung kos yang } \\
\text { mahal. }\end{array}$ & - & - & - & $\begin{array}{c}113 \\
(56.0 \%)\end{array}$ & $\begin{array}{c}87 \\
(43.5 \%)\end{array}$ & 4.44 & 0.50 & Tinggi \\
\hline $\begin{array}{l}\text { Saya berada di sekolah } \\
\text { ini sekarang kerana } \\
\text { keperluan serta } \\
\text { keinginan. }\end{array}$ & - & - & $\begin{array}{c}1 \\
(0 . \\
5 \%) \\
\end{array}$ & $\begin{array}{c}49 \\
(24.5 \%)\end{array}$ & $\begin{array}{c}150 \\
(75.0 \%)\end{array}$ & 4.75 & 0.45 & Tinggi \\
\hline $\begin{array}{l}\text { Saya tidak mempunyai } \\
\text { banyak pilihan yang } \\
\text { membolehkan saya } \\
\text { berhenti kerja. }\end{array}$ & - & $\begin{array}{c}1 \\
(0 \\
5 \%) \\
\end{array}$ & $\begin{array}{c}2 \\
(1.0 \\
\%) \\
\end{array}$ & $\begin{array}{c}101 \\
(50.5 \%)\end{array}$ & $\begin{array}{c}96 \\
(48.0 \%)\end{array}$ & 4.46 & 0.55 & Tinggi \\
\hline $\begin{array}{l}\text { Akibat yang serius } \\
\text { dengan meninggalkan } \\
\text { sekolah ini adalah } \\
\text { kemungkinan } \\
\text { menghadapi masalah } \\
\text { kekurangan pilihan } \\
\text { kerja. }\end{array}$ & - & $\begin{array}{c}1 \\
(0 . \\
5 \%)\end{array}$ & $\begin{array}{c}8 \\
(4.0 \\
\%)\end{array}$ & $\begin{array}{c}43 \\
(21.5 \%)\end{array}$ & $\begin{array}{c}148 \\
(74.0 \%)\end{array}$ & 4.69 & 0.57 & Tinggi \\
\hline
\end{tabular}


DOI: https://doi.org/10.47405/mjssh.v5i6.434

\begin{tabular}{|c|c|c|c|c|c|c|c|c|}
\hline $\begin{array}{l}\text { Salah satu sebab utama } \\
\text { kenapa saya terus } \\
\text { bekerja dengan sekolah } \\
\text { ini ialah kerana ia } \\
\text { memerlukan } \\
\text { pengorbanan untuk } \\
\text { keluar. Sekolah lain } \\
\text { mungkin tidak dapat } \\
\text { menandingi faedah yang } \\
\text { saya perolehi di sini. }\end{array}$ & - & - & $\begin{array}{c}1 \\
(0.5 \\
\%)\end{array}$ & $\begin{array}{c}101 \\
(50.5 \%)\end{array}$ & $\begin{array}{c}98 \\
(49.0 \%)\end{array}$ & 4.49 & 0.51 & Tinggi \\
\hline $\begin{array}{l}\text { Saya berasa pekerja } \\
\text { sekarang terlalu kerap } \\
\text { bertukar dari sebuah } \\
\text { sekolah ke sekolah yang } \\
\text { lain. }\end{array}$ & - & - & $\begin{array}{c}4 \\
(2.0 \\
\%)\end{array}$ & $\begin{array}{c}57 \\
(28.5 \%)\end{array}$ & $\begin{array}{c}139 \\
(69.5 \%)\end{array}$ & 4.68 & 0.51 & Tinggi \\
\hline
\end{tabular}

Sebanyak 7 item telah digunakan untuk mengkaji aspek komitmen normatif. Dapatan analisis ditunjukkan seperti dalam jadual 5.

Jadual 5: Kekerapan, Peratusan, Min dan Sisihan Piawai bagi Item- item Aspek Komitmen Normatif

\begin{tabular}{|c|c|c|c|c|c|c|c|c|}
\hline Item & $\begin{array}{c}\text { Sangat } \\
\text { Tidak } \\
\text { Bersetuju } \\
\end{array}$ & $\begin{array}{c}\text { Tidak } \\
\text { Setuju }\end{array}$ & $\begin{array}{l}\text { Tidak } \\
\text { Pasti }\end{array}$ & Setuju & $\begin{array}{l}\text { Sangat } \\
\text { Setuju }\end{array}$ & Min & $\begin{array}{l}\text { Sisihan } \\
\text { Piawai }\end{array}$ & Tahap \\
\hline $\begin{array}{l}\text { Saya berasa } \\
\text { seseorang itu } \\
\text { mestilah sentiasa } \\
\text { setia kepada } \\
\text { sekolahnya. } \\
\end{array}$ & $\begin{array}{c}1 \\
(0.5 \%)\end{array}$ & - & $\begin{array}{c}2 \\
(1.0 \%)\end{array}$ & $\begin{array}{c}84 \\
(42.0 \\
\%)\end{array}$ & $\begin{array}{c}113 \\
(56.5 \\
\%)\end{array}$ & 4.54 & 0.58 & Tinggi \\
\hline $\begin{array}{l}\text { Pada saya perbuatan } \\
\text { melompat dari } \\
\text { sebuah sekolah ke } \\
\text { sekolah lain adalah } \\
\text { tidak beretika. }\end{array}$ & - & - & $\begin{array}{c}1 \\
(0.5 \%)\end{array}$ & $\begin{array}{c}43 \\
(21.5 \\
\%)\end{array}$ & $\begin{array}{c}156 \\
(78.0 \\
\%)\end{array}$ & 4.78 & 0.43 & Tinggi \\
\hline $\begin{array}{l}\text { Saya percaya bahawa } \\
\text { kesetiaan merupakan } \\
\text { unsur penting. Oleh } \\
\text { itu saya berasa } \\
\text { bertanggungjawab } \\
\text { untuk terus kekal di } \\
\text { sekolah ini. }\end{array}$ & - & - & $\begin{array}{c}3 \\
(1.5 \%)\end{array}$ & $\begin{array}{c}75 \\
(37.5 \\
\%)\end{array}$ & $\begin{array}{c}122 \\
(61.0 \\
\%)\end{array}$ & 4.60 & 0.52 & Tinggi \\
\hline $\begin{array}{l}\text { Sekiranya saya } \\
\text { mendapat tawaran } \\
\text { kerja yang lebih baik } \\
\text { di tempat lain, saya } \\
\text { rasa adalah tidak baik } \\
\text { untuk meninggalkan } \\
\text { sekolah ini. }\end{array}$ & - & - & - & $\begin{array}{c}34 \\
(17.0 \\
\%)\end{array}$ & $\begin{array}{c}166 \\
(83.0 \\
\%)\end{array}$ & 4.83 & 0.38 & Tinggi \\
\hline $\begin{array}{l}\text { Saya diasuh untuk } \\
\text { mempercayai } \\
\text { pentingnya kesetiaan } \\
\text { yang berterusan } \\
\text { terhadap sesebuah } \\
\text { sekolah. } \\
\end{array}$ & - & - & $\begin{array}{c}2 \\
(1.0 \%)\end{array}$ & $\begin{array}{c}165 \\
(82.5 \\
\%)\end{array}$ & $\begin{array}{c}33 \\
(16.5 \\
\%)\end{array}$ & 4.16 & 0.39 & Tinggi \\
\hline $\begin{array}{l}\text { Adalah lebih baik } \\
\text { sekiranya seseorang } \\
\text { pekerja itu kekal } \\
\text { dengan sebuah } \\
\text { sekolah untuk } \\
\text { sebahagian besar }\end{array}$ & - & - & $\begin{array}{c}4 \\
(2.0 \%)\end{array}$ & $\begin{array}{c}132 \\
(66.0 \\
\%)\end{array}$ & $\begin{array}{c}64 \\
(32.0 \\
\%)\end{array}$ & 4.30 & 0.50 & Tinggi \\
\hline
\end{tabular}




\begin{tabular}{|c|c|c|c|c|c|c|c|c|}
\hline kerjaya mereka. & & & & & & & & \\
\hline $\begin{array}{l}\text { Saya berasa bahawa } \\
\text { keinginan seseorang } \\
\text { untuk mendedikasi } \\
\text { dirinya kepada } \\
\text { sesebuah sekolah } \\
\text { adalah tindakan yang } \\
\text { munasabah. }\end{array}$ & - & - & $\begin{array}{c}1 \\
(0.5 \%)\end{array}$ & $\begin{array}{c}106 \\
(53.0 \\
\%)\end{array}$ & $\begin{array}{c}93 \\
(46.5 \\
\%)\end{array}$ & 4.46 & 0.51 & Tingg \\
\hline
\end{tabular}

Dalam proses penganalisisan data terhadap hubungan antara gaya kepemimpinan transformasi gurubesar dengan komitmen kerja guru, analisis inferensi Korelasi Pearson digunakan bagi mengganalisis hubungan antara pembolehubah-pembolehubah kajian ini. Dapatan ini menunjukkan bahawa, terdapat hubungan yang signifikan antara gaya kepemimpinan transformasi gurubesar dengan komitmen kerja guru dari Sekolah Jenis Kebangsaan Tamil di daerah Kulim Bandar Baharu.

Jadual 6: Keputusan Korelasi Pearson antara Gaya Kepemimpinan Transformasi Guru Besar dengan Komitmen Kerja Guru

\begin{tabular}{lccc}
\hline & & \multicolumn{2}{c}{ Komitmen kerja guru } \\
\hline $\begin{array}{l}\text { Kepimpinan } \\
\text { trasformasi guru besar }\end{array}$ & Korelasi Pearson & 1 & $.302^{* *}$ \\
& Sig. (2-hala) & & .000 \\
& $\mathrm{~N}$ & 200 & 200 \\
\hline
\end{tabular}

**Korelasi adalah signifikan pada aras 0.01 (2 hala).

Dapatan juga menunjukkan nilai mata korelasi yang positif $(r=0.302, p=0.000)$. Nilai signifikan $\mathrm{p}$ adalah lebih kecil daripada aras signifikan yang ditetapkan iaitu 0.01 . Hubungan yang positif secara signifikan menunjukkan gaya kepemimpinan transformasi gurubesar yang tinggi mempunyai komitmen kerja guru yang tinggi manakala gaya kepemimpinan transformasi gurubesar yang rendah mempunyai komitmen kerja guru yang rendah $(\mathrm{r}=0.302)$. Maka hipotesis nol ditolak.

Persoalan yang ketiga ialah analisis hubungan antara dimensi-dimensi gaya kepemimpinan transformasi guru besar (Karismatik, Pertimbangan Individu, Stimulasi Intelektual, Motivasi Inspirasi) dengan Komitmen Kerja Guru. Dapatan in menunjukkan bahawa terdapat hubungan yang signifikan antara dimensi-dimensi gaya kepemimpinan transformasi guru besar (karismatik, motivasi inspirasi, stimulasi intelektual dan pertimbangan secara individu) dengan komitmen kerja dalam kalangan guru Sekolah Jenis Kebangsaan Tamil di daerah Kulim Bandar Baharu. Dapatan juga menunjukkan nilai mata korelasi yang positif bagi kesemua dimensi-dimensi gaya kepemimpinan transformasi guru besar. Pertama, dimensi karismatik menunjukkan hubungan yang positif dan didapati signifikan $(r=0.206, p=$ $0.003, \mathrm{p}<0.01)$ secara statistik dengan komitmen kerja. Kedua, dimensi pertimbangan secara individu turut menunjukkan hubungan yang positif dan didapati signifikan $(r=0.224, p=0.001, p<0.01)$ secara statistik dengan komitmen kerja guru. Ketiga, dimensi stimulasi intelektual pula menunjukkan hubungan yang positif dan didapati signifikan $(\mathrm{r}=0.242, \mathrm{p}=0.001, \mathrm{p}<0.01)$ secara statistik dengan komitmen kerja guru. Dimensi yang ke empat iaitu motivasi inspirasi turut menunjukkan hubungan yang positif dan didapati signifikan $(\mathrm{r}=0.189, \mathrm{p}=0.007, \mathrm{p}<0.001)$ secara statistik. Nilai signifikan $\mathrm{p}$ bagi kesemua dimensi-dimensi gaya kepemimpinan transformasi guru besar adalah lebih kecil daripada aras signifikan yang ditetapkan iaitu 0.01 . Secara keseluruhannya, hubungan yang positif secara signifikan menunjukkan amalan dimensi-dimensi gaya kepemimpinan transformasi guru besar (karismatik, motivasi inspirasi, stimulasi intelektual dan pertimbangan secara individu) yang tinggi mempunyai komitmen kerja yang tinggi manakala amalan dimensi-dimensi gaya kepemimpinan transformasi guru besar (karisma, motivasi inspirasi, stimulasi intelektual dan pertimbangan secara individu) yang rendah mempunyai komitmen kerja guru yang rendah. Maka hipotesis nol ditolak. 
Berdasarkan kepada dapatan analisis inferensi yang telah dijalankan, maka dapat dirumuskan bahawa kedua-dua hipotesis yang dibina, satu telah ditolak. Rumusan hipotesis penyelidikan ini telah dipaparkan dalam jadual di bawah:

Jadual 7: Rumusan Hipotesis kajian

\begin{tabular}{lll}
\hline Hipotesis & \multicolumn{1}{c}{ Pernyataan } & Dapatan \\
\hline Ho 1 & Tidak terdapat hubungan yang signifikan & \\
& antara pandangan guru terhadap gaya Hipotesis nol ditolak \\
& kepemimpinan transformasi guru besar & \\
& dengan komitmen kerja guru Sekolah Jenis \\
& Kebangsaan Tamil di Kulim Bandar Baharu. \\
\hline Ho 2 & Tidak terdapat hubungan yang signifikan \\
& antara dimensi-dimensi gaya kepemimpinan Hipotesis nol ditolak \\
& transformasi guru besar (karismatik, motivasi \\
& inspirasi, stimulasi intelektual dan \\
& pertimbangan secara individu) dengan \\
& komitmen kerja dalam kalangan guru-guru \\
& Sekolah Jenis Kebangsaan Tamil di daerah \\
& Kulim Bandar Baharu. & \\
\end{tabular}

Secara keseluruhannya, kajian ini telah memberikan keputusan kepada persoalan-persoalan kajian serta hipotesis-hipotesis kajian yang telah dibina. Dapatan kajian deskriptif menunjukkan bahawa komitmen kerja dalam kalangan guru Sekolah Jenis Kebangsaan Tamil di daerah Kulim Bandar Baharu adalah pada tahap yang tinggi. Seterusnya dalam bahagian pengujian hipotesis pula, kedua-dua hipotesis nol dalam kajian ini telah ditolak berdasarkan keputusan analisis Korelasi Pearson. Dapatan kajian menunjukkan bahawa terdapat hubungan yang signifikan antara pandangan guru terhadap gaya kepemimpinan transformasi guru besar dengan komitmen kerja guru Sekolah Jenis Kebangsaan Tamil di daerah Kulim Bandar Baharu, Kedah. Selain itu, dapatan kajian juga membuktikan bahawa terdapat hubungan yang signifikan antara dimensi-dimensi gaya kepemimpinan transformasi guru besar (karismatik, motivasi inspirasi, stimulasi intelektual dan pertimbangan secara individu) dengan komitmen kerja dalam kalangan guru Sekolah Jenis Kebangsaan Tamil di daerah Kulim Bandar Baharu.

\section{Rumusan Kajian}

Kajian ini dijalankan bagi mengkaji hubungan antara gaya kepemimpinan transformasi guru besar dengan komitmen kerja guru Sekolah Jenis Kebangsaan Tamil di daerah Kulim Bandar Baharu, Kedah. Sebanyak 200 set soal selidik telah dijawab oleh guru-guru dari 17 buah Sekolah Jenis Kebangsaan Tamil di daerah Kulim Bandar Baharu. Instrumen Organizational Commitment Questionnaire (OCQ) yang dibina oleh Allen dan Meyer (1990) digunakan bagi mengukur tahap komitmen kerja guru yang menjadi persoalan pertama kajian ini. Kedua, instrumen Multifactor Leadership Questionnaire (MLQ5x) yang dibina oleh Bass dan Avolio (2000) digunakan bagi mengkaji gaya kepemimpinan transformasi yang menjadi pembolehubah bebas dalam kajian ini.

Dalam proses penganalisisan data, analisis deskriptif digunakan bagi mengukur tahap komitmen kerja dalam kalangan guru Sekolah Jenis Kebangsaan Tamil di daerah Kulim Bandar Baharu. Dapatan analisis menunjukkan tahap komitmen kerja dalam kalangan guru Sekolah Jenis Kebangsaan Tamil di daerah Kulim Bandar Baharu adalah tinggi dalam kajian ini. Maka, dapatan ini telah menjawab persoalan pertama kajian ini. Seterusnya, analisis inferensi Korelasi Pearson digunakan bagi menjawab persoalan kajian yang kedua dan ketiga. Dapatan analisis inferensi menunjukkan terdapat hubungan yang signifikan antara pandangan guru terhadap gaya kepemimpinan transformasi guru besar dengan komitmen kerja guru-guru Sekolah Jenis Kebangsaan Tamil di daerah Kulim Bandar Baharu. Selain itu, analisis inferensi turut menunjukkan terdapat hubungan yang signifikan antara dimensi-dimensi gaya kepemimpinan transformasi guru besar (karismatik, motivasi inspirasi, stimulasi intelektual dan 
pertimbangan secara individu) dengan komitmen kerja dalam kalangan guru-guru Sekolah Jenis Kebangsaan Tamil di daerah Kulim Bandar Baharu.

Tahap tinggi komitmen kerja guru dalam kalangan guru Sekolah Jenis Kebangsaan Tamil di daerah Kulim Bandar Baharu ini menunjukkan golongan ini memberikan komitmen penuh terhadap kepemimpinan sekolah. Para guru yang menjadi responden kajian ini adalah boleh dikatakan mempunyai kesetiaan, identifikasian serta penglibatan dalam sekolah yang tinggi sebagai tempat pekerjaan (Meyer \& Allen, 1997). Selain itu dapatan kajian ini selari dengan Wu (2003) serta Lagomarsino dan Cardona (2003). Kedua-dua kajian ini menunjukkan gaya kepemimpinan guru besar mampu meningkatkan tahap komitmen kerja guru. Menurut kajian-kajian ini, gaya kepemimpinan ketua jabatan di sekolah mampu mengubah aras tahap komitmen kerja guru. Jadi, pengekalan gaya kepemimpinan yang menitikberatkan kepentingan guru-guru mampu meningkatkan komitmen kerja guru di sekolah.

\section{Implikasi Kajian}

Berdasarkan kepada hasil kajian yang diperoleh, didapati bahawa gaya kepemimpinan transformasi guru besar mempunyai hubungan yang signifikan dengan komitmen kerja guru Sekolah Jenis Kebangsaan Tamil di daerah Kulim Bandar Baharu. Oleh itu, beberapa cadangan atau langkah boleh dilaksanakan bagi meningkatkan komitmen kerja guru di sekolah. Dalam pada itu, bagi melahirkan guru-guru yang berkomitmen tinggi para guru besar perlu mengamalkan gaya kepemimpinan transformasi supaya persekitaran sekolah menjadi kondusif untuk guru-guru bagi melaksanakan tugas harian mereka. Hal ini adalah penting kerana apabila para guru mula merasakan minat terhadap gaya kepemimpinan guru besar maka tahap komitmen kerja guru turut akan meningkat. Komitmen kerja guru merupakan pembolehubah yang sangat penting kepada peningkatan prestasi organisasi (Hoy dan Miskel, 2005; Mowday et al., 1982).

Selain itu, para guru besar yang baru dilantik perlu diberikan pendedahan yang mendalam dalam Program Kelayakan Profesional Pemimpin Pendidikan Kebangsaan (NPQEL) yang ditawarkan kepada golongan ini sebagai syarat lantikan. Dalam pada itu, kursus seumpama ini perlu juga ditawarkan kepada guru besar-guru besar yang telah lama dilantik sebelum Program Kelayakan Profesional Pemimpin Pendidikan Kebangsaan (NPQEL) ini diperkenalkan. Apabila kursus-kursus ini ditawarkan kepada kesemua guru besar atau pengetua baru dan lama maka pentadbiran bergaya kepemimpinan transformasi dapat diamalkan serta diselaraskan di semua peringkat sekolah. Di samping itu, peruntukan khas perlu disediakan oleh Kementerian Pelajaran Malaysia bagi menganjurkan bengkel, seminar atau kursus bagi memotivasikan diri para guru supaya dapat meningkatkan tahap komitmen kerja guru. Selain itu, para guru harus dipupuk supaya bekerjasama dengan pemimpin sekolah dalam situasi-situasi yang mencabarkan. Para guru perlu dibentuk supaya menjadi golongan yang berkomitmen tinggi terhadap visi dan misi sekolah supaya dapat berganding bahu dengan corak pentadbiran bagi meningkatkan kecemerlangan sekolah. Walaubagaimanapun, para guru besar dan para guru disarankan mengamalkan tabiat pembelajaran sepanjang hayat supaya dapat meningkatkan pengetahuan mereka terhadap gaya kepemimpinan transformasi serta komitmen kerja guru. Pengetahuan yang mendalam serta meluas menjadikan setiap anggota sekolah bergerak mengikut perubahan arus pendidikan secara global.

Pemboleh-pembolehubah dari kajian ini disarankan bagi menggunakan metodologi yang berbeza iaitu kaedah kualitatif atau pergandingan kaedah kualitatif dan kuantitatif. Penggunaan kaedah kualitatif dapat membantu bagi membuat perbandingan dapatan kajian antara kaedah kuantitatif dan kaedah kualitatif. Maka, hasil kajian yang diperolehi akan menjadi lebih realistik dan dapat dikaitkan situasi sekolah yang sebenar. 


\section{Kesimpulan}

Kesimpulannya, hasil kajian ini mendapati bahawa tahap komitmen kerja dalam kalangan guru Sekolah Jenis Kebangsaan Tamil di daerah Kulim Bandar Baharu adalah tinggi. Selain itu, kajian menunjukkan bahawa terdapat hubungan signifikan yang positif dan rendah antara pandangan guru terhadap gaya kepemimpinan transformasi guru besar dengan komiten kerja guru Sekolah Jenis Kebangsaan Tamil di daerah Kulim Bandar Baharu. Seterusnya, kajian ini turut mendapati bahawa terdapat hubungan signifikan yang positif dan lemah antara dimensi-dimensi gaya kepemimpinan transformasi guru besar (karismatik, motivasi inspirasi, stimulasi intelektual dan pertimbangan secara individu) dengan komitmen kerja guru Sekolah Jenis Kebangsaan Tamil di daerah Kulim Bandar Baharu. Dalam era globalisasi ini, organisasi sekolah memang memerlukan pemimpin yang bukannya semata-mata menjadi seorang pengurus tetapi harus berfungsi sebagai seorang pemimpin yang berwawasan, berkarismatik, berkemampuan merangsang intelek, bermotivasi inspirasi dan bertimbang rasa secara individu. Pemimpin sekolah yang mengamalkan gaya kepemimpinan transformasi dapat meningkatkan tahap komitmen kerja guru lalu membentuk organisasi sekolah yang cemerlang, gemilang dan terbilang.

\section{Rujukan}

Abdul Ghani Abdullah. (2005). Kepimpinan transformasi pengetua dan penggantian kepimpinan sebagai penentu komitmen terhadap organisasi dan perlakuan warga organisasi pendidikan. Jurnal Pendidik dan Pendidikan, 20, 53-68.

Abdul Ghani Abdullah \& Tang, K. W. (2006). Motivasi guru dan pengurusan budaya kolaboratif pengurus pendidikan wanita. Jurnal Pendidikan, 31, 97-105.

Affizal Ahmad \& Rafidah Sahak. (2009). Teacher-student attachment and teachers'attitudes towards work. Jurnal Pendidik dan Pendidikan, 24, 55-72.

Bass, B. M. (1990). Bass and stogdill's handbook of leadership theory, research and managerial applications, $3^{\text {rd }}$ edition. New York: The Free Press.

Bass, B., \& Avolio, B. (1993). Transformational leadership and organizational culture. Public Administration Quarterly, 17, 112-121.

Fauziah, N., Rahmah, M. R., Rohani, G., \& Rasimah, A. (2008). Teacher Professional And Organisational Commitment: Evidence From Malaysia. TLC Conference Proceeding. Rothenburg: Germany: EABR.

Gay, L. R., \& Airasian, P. (2003). Educational Research Competencies for Analysis Application. Prentice Hall. 367-429

Hoy, W. K., \& Miskel, C. G. (2005). Educational administration: Theory, research and practice. 7th edition. New York: McGraw-Hill.

Ishak Bin Sin. (2004). Apakah Yang Tertulis Dalam Khazanah Tulisan Ilmiah Tentang Tret, Tingkah Laku dan Tindakan Yang Diperlukan Untuk Menjadi Seorang Pengetua Yang Cemerlang?. Prosiding Seminar Nasional Pengurusan dan Kepimpinan.

Insim-Park. (2005). Teacher commitment and its effects on students achievement in American high schools. Educational Research and Evaluation, 1(5),401-485.

Lagomarsino, R., Cardona S. P. (2003). Relationships among leadership, organizational commitment, and ocb in uruguayan health institutions", IESE, DI-494-E, 02/2003.

Lunenberg, F. C. \& Ornstein, A. C. (2000). Educational administration concepts and practices, $3^{\text {rd }}$ edition. Belmont, CA: Wadsworth Thomson Learning.

Lunenberg, F.C., \& Omstein, A.C. (2001). Educational Administration: Concept and Practises. $\left(4^{\text {th }}\right.$ ed.). California. Wadsworth Publishing Company.

Lunenburg, C. F. (2003). Emerging perspectives: The usefulness of the construct of transformational leadership in educational organizations. Paper presented at the Annual Meeting of the Cational Council of Professors of Educational Administration, Sedona.

Meyer, J. P., \& Allen, N. J. (1997). Commitment in the workplace: Theory, research and application . Newbury Park, CA: Sage.

Mosadeghrad, A.M. (2003). Principles of Health Care Administration.Tehran: Dibagran Tehran 
Mowday, R. T., Steers, R. W., \& Porter, L. W. (1979). The measurement of organizational commitment. Journal of Vocational Behavior, 14(2), 224-247.

Mowday, R.T., Steers, R.W., \& Porter, L.W. (1982). Employee organization lingkage: The psychology of commitment. New York: Academic Press.

Nik Azis Nik Pa. (2003). Penggunaan teori dan kerangka teori dalam penyelidikan pendidikan Matematik. Masalah Pendidikan, 26, 29-61.

Rosenbach, W. E. \& Taylor, R. L. (2001). Contemporary issues in leadership (5 $5^{\text {th }}$ ed). Boulder, CO: Westview Press.

Sergiovanni, T. J. (2001). The principalship a reflective practice perspectives, $4^{\text {th }}$ edition. Needham Heights, MA: Allyn and Bacon.

S. G. A. Smeenk, R. N. Eisinga, J. C, Teelken and J. A. C. M. Dooreward. (2006). The effect of HRM practices and antecedents on organizational commitment among university employees. International Journal of Human Resources Management 17.

$\mathrm{Wu}, \mathrm{A}$. (2003). The role of transformational leadership in anhancing innovation: Hypotheses and some preliminary findings. Leadership Quarterly, 14, 525-544.

Yaakob Daud (2007). Budaya sekolah: Hubungannya dengan kepemimpinan, komitmen organisasi dan pencapaian akademik murid sekolah rendah. Tesis Doktor Falsafah Pendidikan Yang Tidak Diterbitkan, Universiti Sains Malaysia.

Yukl, G. (2002). Leadership In Organizations, $5^{\text {th }}$ edition, Upper Saddle, New Jersey: Prentice Hall International, Inc.

Sergiovanni (2001). Interstate School Leaders Licensure Consortium. 